\title{
Alterations of blood flow pattern after triple stent endovascular treatment of saccular abdominal aortic aneurysm: a porcine model.
}

\section{Alterações do padrão do fluxo sanguíneo após tratamento endovascular do aneurisma sacular da aorta abdominal com triplo stent: modelo em suínos.}

Jahir Richard de Oliveira'; Maurício de Amorim Aquino1; Svetlana Barros²; Guilherme Benjamin Brandão Pitta3; Adamastor Humberto Pereira ${ }^{3}$.

\begin{abstract}
A B S T R A C T
Objective: to determine the blood flow pattern changes after endovascular treatment of saccular abdominal aortic aneurysm with triple stent. Methods: we conducted a hemodynamic study of seven Landrace and Large White pigs with saccular aneurysms of the infrarenal abdominal aorta artificially produced according to the technique described. The animals were subjected to triple stenting for endovascular aneurysm. We evaluated the pattern of blood flow by duplex scan before and after stent implantation. We used the non-paired Mann-Whitney test for statistical analysis. Results: there was a significant decrease in the average systolic velocity, from $127.4 \mathrm{~cm} / \mathrm{s}$ in the pre-stent period to $69.81 \mathrm{~cm} / \mathrm{s}$ in the post-stent phase. There was also change in the flow pattern from turbulent in the aneurysmal sac to laminate intra-stent. Conclusion: there were changes in the blood flow pattern of saccular abdominal aortic aneurysm after endovascular treatment with triple stent.
\end{abstract}

Keywords: Regional Blood Flow. Sacular Aneurysm. Aortic Aneurysm, Abdominal. Stents. Swine.

\section{INTRODUCTION}

$\mathrm{T}$ he endovascular treatment of abdominal aortic aneurysms has become an increasingly used surgical alternative instead of traditional surgery'. Treatment is successful when there is full suppression of blood flow and systemic pressure in the aneurysmal sac, which prevent rupture ${ }^{2-4}$. Although we have achieved significant technological advances since the first generation of aortic stents, recent information from late postoperative follow-up have shown a significant percentage of complications requiring surgical reintervention. The reason for treatment failure, in many cases, is still connected to the endoprosthesis used (type III leakage) ${ }^{5-7}$.

Studies have focused on the deterioration of the currently marketed prosthetic material, which is made by the association of a metal structure with PTFE or polyester coating ${ }^{8-10}$. Thus arises a new therapeutic method, based on experimental haemodynamic studies, the multilayered stents: uncoated metal prostheses, capable of promoting redirection of blood flow within the aneurysm sac, preventing its expansion and rupture, even without total flow abolition in the aneurysmal sac ${ }^{8-14}$.

The aim of this study is to experimentally analyze the effects of the implant, in pigs, of three stents with the same design (triple stent) on the redirection of blood flow of the aneurysmal sac, and to determine possible changes in the abdominal aorta blood flow pattern after treatment.

\section{METHODS}

The research project was approved by the Ethics in Research Committee of the Universidade Estadual de Ciências da Saúde de Alagoas (UNCISAL) Protocol 61$A$, and strictly followed the ethical principles of animal experimentation of the Colégio Brasileiro de Experimentação Animal (COBEA), based on Resolution 714/02 of the Conselho Federal de Medicina Veterinária ${ }^{15,16}$.

The sample consisted of seven female pigs from the crossing of Landrace and Large White, weighing 20 to $25 \mathrm{~kg}$, supplied by the same producer, proper-

1 - Universidade Federal do Rio Grande do Sul (UFRGS), Porto Alegre, RS, Brasil; 2 - Universidade Estadual de Ciências da Saúde de Alagoas (UNCISAL), Maceió, AL, Brasil; 3 - Programa de Pós-Graduação em Ciências Cirúrgicas do Departamento de Cirurgia da Faculdade de Medicina da Universidade Federal do Rio Grande do Sul (UFRGS), Porto Alegre, RS, Brasil. 
ly vaccinated and dewormed according to the age. We submitted them to the artificial production of infrarenal abdominal aortic aneurysms according to the modified technique of Perini ${ }^{17}$ as described: transabdominal exposure of the abdominal aorta, with xyphopubic median incision, followed by aortic exposure through circumferential dissection between the renal arteries and the distal trifurcation (common iliac arteries and internal iliac artery trunk); election of a $3 \mathrm{~cm}$ segment for making of the aneurysm, the branches repaired with 3.0 linen thread, and administered intravenous heparin (100IU/kg); clamping of the aorta proximal and distal to the chosen segment and conduction of a longitudinal arteriotomy followed by the patch suture with bovine pericardium in the form of a previously prepared bag of $3 \times 3 \mathrm{~cm}, 6.0$ polypropylene continuous sutures (Figure 1); Fifteen days after surgery, we performed Duplex Scan evaluation to confirm the aneurysms patency, as well as analyze the pre-stenting blood flow parameters. Then they underwent triple stent implantation and reevaluation of blood flow to assess the variables. Anesthesia was performed following the CCEB/ UNCISAL general anesthesia protocol for porcine.

\section{Stents Implantation}

Vascular access to aortography was obtained by surgical dissection of the right femoral artery, and the arterial puncture performed under direct vision with a 16 Jelco catheter. After the advance of a $0.035 \times 260 \mathrm{~cm}$ angled tip hydrophilic guidewire, we introduced a $11 \mathrm{~cm} \mathrm{5F}$

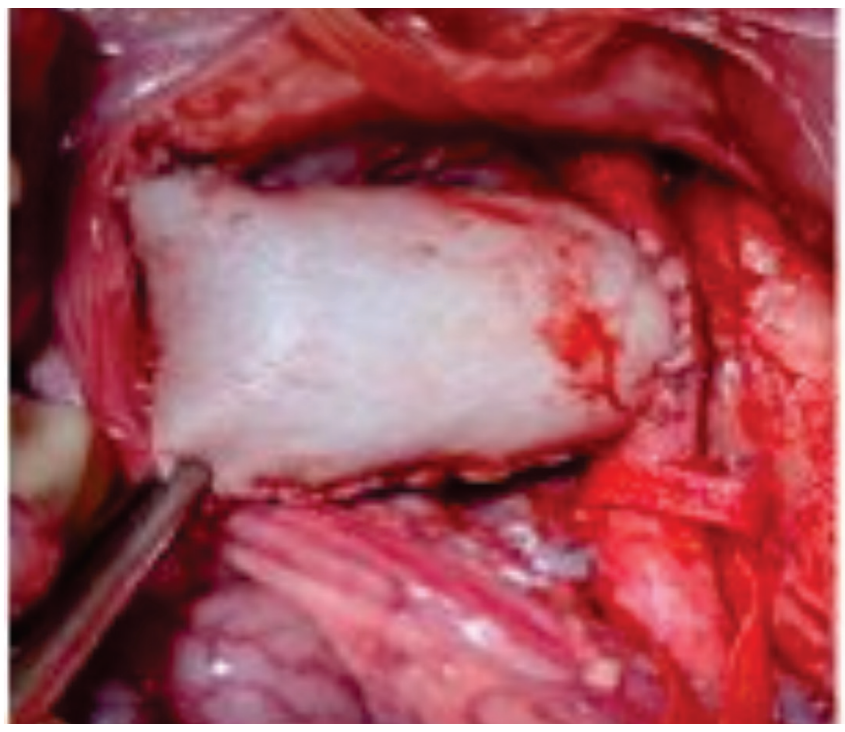

Figure 1. Saccular aneurysm after blood flow release. sheath. We advanced the sheath under fluoroscopic control until the common iliac artery. Further, we performed the aortography with a $100 \mathrm{~cm} 5 \mathrm{~F} \mathrm{MP}$ angiographic catheter to identify the aneurysm, follow by the positioning of the catheter in the thoracic aorta, above the aneurysm site.

We later performed the vascular access for the implantation of stents through surgical dissection of the right carotid artery, the arterial puncture being performed under direct vision with a 16 Jelco. After the advance of $0.035 \times 260 \mathrm{~cm}$ angled tip hydrophilic guidewire, we introduced a $11 \mathrm{~cm} 7 \mathrm{~F}$ sheath. We advanced the sheath under fluoroscopic control until the aortic arch, and positioned the guidewire in the thoracic aorta with the aid of an IM catheter.

After positioning of the femoral catheter within the aneurysmal sac to angiographic control, we proceded to the sequential insertion with deployment of the stents through the right carotid artery, in the following order of sizes: $8 \times 40 \mathrm{~mm}, 9 \times 40 \mathrm{~mm}$ and $10 \times 40 \mathrm{~mm}$, starting the deployment from the porcine aorta trifurcation. Then, we carreid out a control aortography with a 5F MP angiographic catheter via the right carotid artery (Figure 2).

The nitinol stents used in the experiment were manufactured by the company Braile Biomedica (Brazil), of self-expanding type, with an over-the-wire deployment system, compatible with a 7F introducer. The stent features a closed cell design, with monofilament braids in tubular form, in diamond shape, with proximal and distal radiopaque markers in gold.

We recorded the images through the Duplex

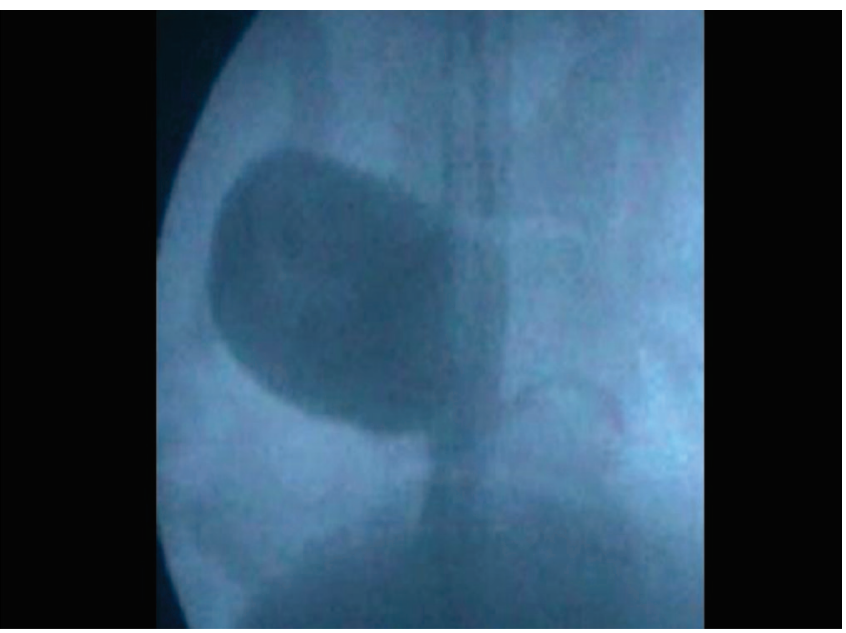

Figure 2. Aortography post-stent implantation. 


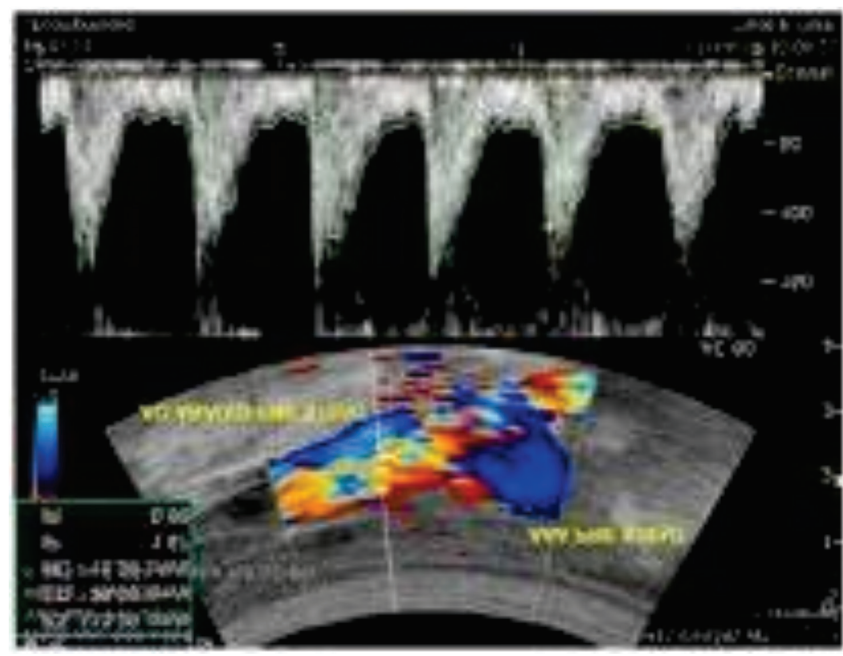

Figure 3. Pre-stent aneurysm in animal 1.

Scan 30 minutes before the stents implantation and 30 minutes after the procedure.

We evaluated the images as for the flow pattern change, turbulent and laminar, as well as for the peak systolic velocity obtained in the aneurysmal aorta. We also evidenced the change of flow pattern from turbulent to laminar after the stent release by aortography.

\section{Study variables \\ Primary Variable}

Change in the blood flow pattern after endovascular treatment of saccular aortic aneurysm. We quantified the flow by vascular ultrasound, using a portable device.

\section{Secondary Variables}

Average blood flow velocity in the aorta; frequency of thrombosis in the aneurysmal sac.

As additional information, we evaluated the averages of the animals ages, of their weights and of the procedure time.

We performed the statistical analysis using the unpaired Mann-Whitney test and calculating the confidence interval $(\mathrm{Cl})$ of $95 \%$ for each point estimate. We evaluated the statistical hypotheses HO (pre-stent flow equals poststent flow) and $\mathrm{H} 1$ (pre-stent flow is not equal post-stent flow) with the GraphPad Instat Prism 5 (2012) statistical program for Windows. The sample size was based on previous studies on the subject conducted in pigs ${ }^{18-21}$.

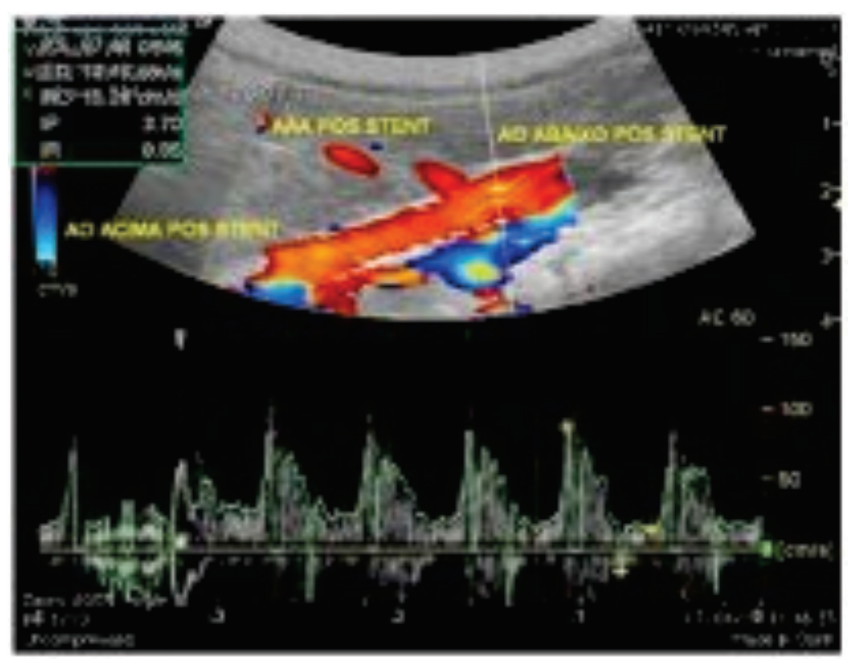

Figure 4. Post-stent aneurysm.

\section{RESULTS}

All seven animals were successfully submitted to implantation of stents without technical difficulty. The surgical procedure time was 190 minutes, and we did not observe any complications such as malposition, migration or inadequate expansion of stents.

In table 1, we describe the quantitative variables that constitute Systolic Peak velocity (PSV) and resistance index (RI) before and after the triple stenting, which revealed significant changes, i.e., loss of systolic velocity after placement of stents, as well as the fall in resistance index in many animals. Regarding systolic velocity, we observed a significant decrease with an average pre-stent velocity $127.4 \mathrm{~cm} / \mathrm{s}(95 \% \mathrm{Cl} 79.93 \pm 0174.8)$ and a mean post-stent velocity $69,81 \mathrm{~cm} / \mathrm{s}(95 \% \mathrm{Cl} 40.18 \pm 99.43)$, confirming the change in blood flow patterns.

The qualitative variables, which represent the change in the flow pattern from turbulent in the aneurysmal sac to laminar intrastent after treatment with triple stent, were demonstrated through the duplex scan (Figures 3 and 4).

\section{DISCUSSION}

The treatment of abdominal aortic aneurysms by endovascular technique has been performed with increasing frequency. This has lead to the increased observation of leaks related to the endoprosthesis ${ }^{6}$, usually due to early defects of components or material fatigue. Recently, a new kind of stent 
Table 1. Distribution of aortic aneurysms blood flow measurements values.

\begin{tabular}{ccccc}
\hline & \multicolumn{3}{c}{ Triple Stent Table } \\
\cline { 2 - 5 } Animal & \multicolumn{2}{c}{ Peak Systolic Velocity cm/s (PSV) } & \multicolumn{2}{c}{ Resistance index (RI) } \\
Pre-stent & 110.29 & 87.49 & $0.6 / 8$ & 0.85 \\
2 & 50.33 & 24.89 & 1.0 & 0.07 \\
3 & 189.86 & 95.43 & 0.88 & 0.67 \\
4 & 163.22 & 86.89 & 1.0 & 0.66 \\
5 & 178.35 & 98.33 & 1.0 & 0.83 \\
6 & 110.39 & 71.23 & 0.87 & 0.76 \\
7 & 89.04 & 24.39 & 0.65 & 1.17 \\
\hline
\end{tabular}

came up that brought a different concept for the treatment of aneurysms ${ }^{12}$. These stents with multiple layers allow the redirection of the flow in the aneurysmal sac, leading to loss of local pressure and preventing expansion.

Several models of assessment of aortic aneurysm flow have been described. Through the dynamics analysis of aortic flow one observes the flow behavior and compares stents and endoprosthesis in the treatment of aortic aneurysms. It is therefore apparent that the pressure and flow pattern changes occur due to change in the systolic velocity during stent use. Augsburger et al., through a silicone aneurysm model, also present findings of changes in the flow pattern, as well as the change in the volume flow after aneurysm stenting ${ }^{13}$. Jiang et al., on their turn, evaluated the default behavior of the flow through angiography and computer simulations of fluid dynamics in dogs with artificially produced aneurysms ${ }^{22}$.

In this pioneering study, we used an experimental model in pigs to assess the changes in the flow pattern with duplex scan after triple stent implantation for the treatment of aortic aneurysm in animals previously submitted to the making of aneurysmal sac with bovine pericardium by the modified Perini technique ${ }^{17}$.

Changes in blood flow pattern in this study were evaluated through duplex scan analysis. Two analyzes were carried out, one in the animal with the aneurysm before the stents implantation, the and other after implantation of stents. We obtained the blood flow pattern analysis and also the parameters systolic velocity and resistance index.

The systolic velocity showed a significant decrease, with an average pre-stent velocity of $127.4 \mathrm{~cm} / \mathrm{s}$ $(95 \% \mathrm{Cl} 79.93 \pm 174.8)$ and a mean post-stent velocity of $69.81 \mathrm{~cm} / \mathrm{s}(95 \% \mathrm{Cl} 40.18 \pm 99.43)$, confirming the change in blood flow patterns.

Images by duplex scan showed change in the flow pattern, ie, from turbulent in the aneurysmal sac to laminar intrastent, the aneurysmal sac presenting with blood flow or excluded. Doppler ultrasonography in pigs showed the possibility to analyze not only the presence of flow within the aneurysmal sac, but also the hemodynamic features of such flow, with more information.

In conclusion, this study showed changes in the blood flow pattern of saccular abdominal aortic aneurysms after endovascular treatment with the triple stent.

\section{R E S U M O}

Objetivo: determinar as alterações do padrão do fluxo sanguíneo após tratamento endovascular do aneurisma sacular de aorta abdominal com triplo stent. Métodos: estudo hemodinâmico de sete suínos das raças Landrace e Large White portadores de aneurismas saculares de aorta abdominal infrarrenal artificialmente produzidos segundo técnica descrita. Os animais foram submetidos a implante de triplo stent para correção endovascular do aneurisma e reavaliados por duplex scan quanto ao padrão do fluxo sanguíneo antes e após o implante dos stents. A análise estatística foi realizada com o teste Mann-Whitney não pareado. Resultados: verificou-se uma queda significativa da velocidade sistólica média de 127,4cm/s na fase pré-stent para 69,81cm/s na fase pós-stent. Houve ainda mudança no padrão do fluxo de turbilhonar no saco aneurismático para laminar intrastent. Conclusão: o estudo demonstrou alterações do padrão do fluxo sanguíneo do aneurisma sacular de aorta abdominal após tratamento endovascular com triplo stent.

Descritores: Fluxo Sanguíneo Regional. Aneurisma Sacular. Aneurisma da Aorta Abdominal. Stents. Suínos. 


\section{REFERENCES}

1. Parodi JC, Palmaz JC, Barone HD. Transfemoral intraluminal graft implantation for abdominal aortic aneurysms. Ann Vasc Surg. 1991;5(6):491-9.

2. Dias NV, Ivancev $K$, Malina $M$, Resch $T$, Lindblad $B$, Sonesson B. Intra-aneurysm sac pressure measurements after endovascular aneurysm repair: differences between shrinking, unchanged, and expanding aneurysms with and without endoleaks. J Vasc Surg. 2004;39(6):1229-35.

3. Ellozy SH, Carroccio A, Lookstein RA, Minor ME, Sheahan CM, Juta J, et al. First experience in human beings with a permanently implantable intrasac pressure transducer for monitoring endovascular repair of abdominal aortic aneurysms. J Vasc Surg. 2004;40(3):405-12.

4. Sonesson B, Dias N, Malina M, Olofsson P, Griffin $D$, Lindblad $B$, et al. Intra-aneurysm pressure measurements in successfully excluded abdominal aortic aneurysm after endovascular repair. J Vasc Surg. 2003;37(4):733-8.

5. Conrad MF, Crawford RS, Pedraza JD, Brewster DC, Lamuraglia GM, Corey M, et al. Long-term durability of open abdominal aortic aneurysm repair. J Vasc Surg. 2007;46(4):669-75.

6. Hobo R, Buth J; EUROSTAR collaborators. Secondary interventions following endovascular abdominal aortic aneurysm repair using current endografts. A EUROSTAR report. J Vasc Surg. 2006;43(5):896-902.

7. Leurs LJ, Buth J, Laheij RJ. Long-term results of endovascular abdominal aortic aneurysm treatment with the first generation of commercially available stent grafts. Arch Surg. 2007;142(1):33-41; discussion 42.

8. Balderi A, Antonietti A, Pedrazzini F, Ferro L, Leotta $L$, Peano $E$, et al. Treatment of a hepatic artery aneurysm by endovascular exclusion using the multilayer cardiatis stent. Cardiovasc Intervent Radiol. 2010;33(6):1282-6.

9. Benjelloun A, Henry M, Ghannam A, Vaislic C, Azzouzi $A$, Maazouzi $W$, et al. Endovascular treatment of a tuberculous thoracoabdominal aneurysm with the multilayer stent. J Endovasc Ther. 2012;19(1):115-20.

10. Canic S, Ravi-Chandar K, Krajcer Z, Mirkovic D, Lapin S. Mathematical model analysis of wallstent and aneurx: dynamic responses of bare-metal endoprosthesis compared with those of stent-graft. Tex Heart Inst J. 2005;32(4):502-6.

11. Euringer W, Südkamp M, Rylski B, Blanke P. Endovascular treatment of multiple HIV-related aneurysms using multilayer stents. Cardiovasc Intervent Radiol. 2012;35(4):945-9.

12. Henry M, Polydorou A, Frid N, Gruffaz P, Cavet A, Henry I, et al. Treatment of renal artery aneurysm with the multilayer stent. J Endovasc Ther. 2008;15(2):231-6.

13. Augsburger L, Farhat M, Asakura F, Ouared R, Stergiopulos $N$, Rüfenacht $D$. Hemodynamical effects of CARDIATIS braided stents in sidewall aneurysm silicone models using PIV. Available from: http:// www.cardiatis.com/images/stories/info/etude $\% 20$ luca\%20in\%20vitro.pdf

14. Liou TM, Li YC. Effects of stent porosity on hemodynamics in a sidewall aneurysm model. J Biomech. 2008;41(6):1174-83.

15. Conselho Federal de Medicina Veterinária. Resolução do Conselho Federal de Medicina Veterinária no 714/02. Disponível em: http://www.cfmv.org.br/ portal/legislacao_resolucoes.php

16. Ibama. Lei Federal 9605/98. Dispõe sobre as sanções penais e administrativas derivadas de condutas e atividades lesivas ao meio ambiente, e dá outras providências. Disponível em: http://www.ibama. gov.br/fauna/legislacao/lei960598.pdf

17. Perini SC. Modelo de aneurisma de aorta abdominal com bolsa de pericárdio bovino [dissertação]. Porto Alegre/RS : Universidade Federal do Rio Grande do Sul, Programa de Pós-Graduação em Medicina; 2008.

18. Castro Júnior C, Pereira AH, Pasa MB. Morphometric analysis of the intimal reaction after stent implantation in iliac arteries submitted to angioplasty in pigs. Acta Cir Bras. 2006;21(3):139- 43.

19. Dutra CF, Pereira AH. Digital morphometric analysis of the aortic wall in pigs following implantation of dacron-covered stents versus non-coverded stents. Acta Cir Bras. 2004;19(3):210-9.

20. França LHG, Pereira AH, Perini SC, Argenta R, Aveline CC, Mollerke RO, et al. Modelo experimental de aneurisma sacular de artéria ilíaca comum com pericárdio bovino em suínos. J vasc bras. 2005;4(4):353-6. 
21. Ferreira LM, Hochman B, Barbosa MVJ. Modelos experimentais em pesquisa. Acta Cir Bras. 2005;20(Suppl 2):28-34.

22. Jiang J, Johnson K, Valen-Sendstad K, Mardal KA, Wieben $\mathrm{O}$, Strother $\mathrm{C}$. Flow characteristics in a canine aneurysm model: a comparison of 4D accelerated phase-contrast MR measurements and computational fluid dynamics simulations. Med Phys. 2011;38(11):6300-12.
Recebido em: 03/01/2016

Aceito para publicação em: 06/04/2016 Conflito de interesse: nenhum.

Fonte de financiamento: nenhuma.

Endereço para correspondência:

Jahir Richard de Oliveira

E-mail: jrichardoliveira@hotmail.com 